\title{
Mobile technology as a health literacy enabler in African rural areas: a literature review
}

\section{Ismaila Ouedraogo ( $\nabla$ lsmaila.Ouedraogo@u-bordeaux.fr )}

University of Bordeaux

\section{Borlli Michel J Some}

Nazi Boni University

\section{Roland Benedikter}

European Academy of Bozen

\section{Gayo Diallo}

University of Bordeaux

\section{Research Article}

Keywords: health literacy, mobile health, mobile technology, rural areas, e-health, local languages, Africa

Posted Date: February 15th, 2021

DOI: https://doi.org/10.21203/rs.3.rs-243773/v1

License: (c) (1) This work is licensed under a Creative Commons Attribution 4.0 International License. Read Full License 


\title{
RESEARCH
}

\section{Mobile technology as a health literacy enabler in African rural areas: a literature review}

\author{
Ismaila Ouedraogo ${ }^{1,3^{*}}$, Borlli Michel J Some ${ }^{1}$, Roland Benedikter ${ }^{2}$ and Gayo Diallo 3,4
}

\author{
${ }^{*}$ Correspondence: \\ Ismaila.Ouedraogo@u-bordeaux.fr \\ ${ }^{3}$ Team ERIAS, BPH Health \\ INSERM 1219, Univ. Bordeaux, \\ F-33000, Bordeaux, France \\ Full list of author information is \\ available at the end of the article
}

\begin{abstract}
Background: Since the launch of mobile phones three decade ago, the latter have been used to support healthcare systems through various mobile health (m-health) applications. In recent years, multiple mobile phone-based health projects and applications have emerged. Despite the great enthusiasm around $\mathrm{m}$-health, few studies have examined the use of cell phones to improve health literacy in Africa. This paper aims to review studies related to the contribution of mobile technologies in improving health literacy in rural areas of Africa.
\end{abstract}

Methods: We performed a four-step systematic review to identify relevant publications: (1) Database selection, (2) Keyword search, (3) Study selection and (4) Data extraction. In addition, manual searching methods were used to find keywords related to $\mathrm{m}$-health initiatives in Africa.

Discussion: Our search resulted in the identification of 38 studies and initiatives related to health literacy and mobile technologies in Africa. However, few of these studies focused on health literacy and mobile technologies in rural areas of Africa. We also found that $m$-health initiatives to date have not been inclusive, with very few integrating local languages in the development of $m$-health solutions. Our findings thus point to various potential avenues to be investigated in the future.

Keywords: health literacy, mobile health, mobile technology, rural areas, e-health, local languages, Africa

\section{Introduction}

Over the past few decades, Africa has experienced rapid transition in terms of mobile connectivity. For instance, the number of smartphone owners almost doubled between 2016 (336 million) and 2020 (660 million), with a penetration rate of 55\% [1]. The growth rate of mobile technologies has had a significant impact on the healthcare sector. According to the mobile industry Group Special Mobile Association (GSMA), over 1,123 cell phone-based projects were planned to be implemented to improve healthcare systems and service delivery [2]. These projects, known as "m-health" projects, have mainly invaded the health landscape of developing countries, since eight out of ten projects are based in Africa. In South Africa alone, 85 m-health initiatives were identified in 2016 [3]. In terms of investment, the global m-health market in the Middle East and Africa reached USD 1.23 billion and is projected to reach USD 5.78 billion by 2025[4]. The enthusiasm for m-health initiatives follows the aspirations of healthcare actors to provide more effective, efficient and equitable healthcare services and information - especially for the most disadvantaged communities in rural areas. Given the complexity of healthcare systems, 
healthcare services spend less time supporting patients nowadays[5]. In rural areas, patients with limited resources face multiple challenges to acquire, understand and use the information they need to make decisions linked to their health (health literacy). Consequently, about $8 \%$ of the African population (from rural areas) is excluded from healthcare services due to the low level of health literacy[6].

\subsection{Low health literacy}

While taking care of our health is part of everyday life, health literacy can help us to prevent health problems and protect our health. It can also help us to better manage any problems or unexpected situations that may occur. According to the US Center for Disease and Control (CDC), health literacy problems occur when organizations or people create and give others health information that is too difficult for them to understand. The World Health Organization (WHO) relates health literacy to "the cognitive and mobile technologies that can enable patients specially with low health literacy to gain rapid access to information patients want and need to maintain and improve their health"[7]. Another definition of health literacy is given by the US Health Resources \& Services Administration as "the degree to which individuals have the capacity to obtain, process, and understand basic health information needed to make appropriate health decisions" [8]. Low health literacy is more prevalent among certain specific categories of people, in particular, among older adults, minority populations, medically underserved people and those with low socioeconomic status. These categories are more frequent in Low- and MiddleIncome Countries (LMICs)[9], including African countries.

\subsection{Mobile technology in Sub-Saharan Africa}

According to GSMA, mobile subscriptions across Sub-Saharan African (SSA) countries will reach over 600 million in 2025, representing almost half the African population [10]. Mobile phones have been used to support healthcare systems through various mobile health (m-health) applications since they were first introduced three decades ago. In Africa, the high penetration rate of mobile phones and the increasing coverage of the mobile network has created many opportunities for the future, and mobile devices can no longer be ignored in health delivery and disease prevention workflows. The global m-health market in Middle-East and Africa is predicted to grow to USD 5.78 billion by 2025, and SSA is forecast to be the fastest growing region in the world [4]. At this point, it is worth acknowledging some initial wellknown m-health successes in Africa built on the unprecedented uptake of mobile services. Several thousand cell phone-based health projects and thousands of health applications have emerged, especially in recent years. Despite the considerable enthusiasm around m-health, few studies have examined the use of mobile phones to improve health literacy in Africa. The continent can nonetheless take advantage of the high and growing penetration rate of cell phone use as a means to promote health and development efforts. To address such challenges, in September 2015, the United Nations (UN) adopted 17 goals to be achieved by 2030 to ensure sustainable development for all. In recent years, many reports have provided evidence of the crucial role that mobile phones can play in achieving the sustainable development goals (SDG)[11]. Taking advantage of the rapid growth of mobile phones to improve 
health literacy in rural areas could indeed help Africa to achieve some of the SDGs listed. Thus, while mobile technologies offer new opportunities for accessing health information and the self-management of health conditions, as far as we know, few studies to date have examined cell phone use in improving health literacy in Africa.

\section{Study Objective}

Our overall aim is to investigate the contribution of mobile technologies to improving health literacy in rural areas of Africa. To this end, we explored studies that address the contribution of mobile technologies to improving health literacy. The current study is part of a wider research project designed to develop a mobile health implementation framework to improve health literacy in rural areas of Africa. Despite the tremendous opportunities that mobile technologies offer, SSA countries in particular face many challenges in implementing mobile phone technology solutions in rural areas[12]. It is also to note that few documented studies in the literature explore health literacy issues in rural Africa based on the utilization of ICT-based solutions such as mobiles phones. The aim of the current literature review is thus to identify existing studies related to mobile technology and health literacy in rural areas of Africa. Its specific aims are:

- to give a general description of health literacy and its defining features;

- to provide a systematic literature review of both studies and initiatives that focus on improving health literacy in rural Africa;

- to highlight the potential benefits of using mobile technology to improve health literacy in Africa and to identify the challenges of existing initiatives;

- to put forward some recommendations to overcome the challenges identified.

\section{Terminological description}

In the following section, we describe the main terms applicable to the topic.

\subsection{Health literacy}

The term "health literacy" refers to the ability to access, understand, assess and apply information in a way that promotes, maintains and improves the health of individuals. However, the WHO defines the term "health literacy" even more broadly as the ability of individuals to "gain access to, understand and use information in ways which promote and maintain good health" for themselves, their families and their communities [13]. At the same time, health literacy, as a concept, includes many skills such as reading, writing, basic arithmetic, learning and speaking. The definition also includes skills related to computers, technologies and cell phones [14]. Health literacy is a key component of public health, and improving the level of health literacy has become a major public health issue[15]. Consumers' ability to search, find, appraise and use health information from the internet is known as an e-health literacy skill. e-health literacy includes a combined set of six basic skills (traditional literacy, health literacy, information literacy, scientific literacy, media literacy and computer literacy)[16].

\section{2 e-health}

e-health, or electronic health, describes the use of new information and communication technologies in the healthcare sector [17]: 
- telehealth, which includes prevention and care actions carried out remotely: information via general public portals, health promotion sites, telephone alert systems, remote electronic prescriptions, etc.;

- telemedicine (medical procedures carried out remotely by a doctor): videoconference consultations, tele-assistance from a doctor during an intervention, tele-monitoring of the patient, tele-expertise (exchange of doctors' opinions);

- m-health (mobile health), which includes digital applications for smartphones or connected objects (bracelets, etc.) related to health;

- electronic health record systems.

\section{3 m-health}

In 2005, Pr. R. Istepanian, a London scholar, used the word "mobile health" or "m-health" for the first time to describe "the use of emerging mobile communications in public health" [18]. Later, in 2009, the WHO defined m-health as "medical and public health practices relying on mobile devices such as cell phones, patient monitoring systems, personal digital assistants and other wireless devices" [19]. As a component of e-health, mobile health represents all the mobile health applications called apps that run on a smartphone, a touchpad or other digital devices (connected watches, etc.). The smartphone can also be the control command for connected objects or the digital interface of many other e-health tools for medical or public health purposes. The United Nations Foundation divided m-health applications into the following key fields[20]:

- Education and awareness

- Remote assistance

- Diagnosis and supportive treatment

- Communication and training for healthcare professionals

- Disease and epidemic monitoring

- Remote monitoring and data collection

\section{4 m-health for education awareness}

The emerging mobile technologies used in healthcare for the purpose of training, screening, supporting and supervising healthcare workers as well as providing healthcare information to individuals are commonly referred to as "m-health Education" or "m-healthEd". Cell phones are often used by organizations or healthcare facilities in developing countries to disseminate health-related messages (e.g., messages about HIV or maternal healthcare) to certain communities. Despite the precarious living conditions experienced by most populations in rural areas, almost everyone has a mobile phone[21]. Extensive SMS systems can be used for health campaigns, and personalized alerts are used to remind patients of specific issues. If the patients or individuals do not have a mobile phone, the messages are sent to the community health workers who can share the information with the rest of the community. In the context of world pandemics (e.g., Ebola, COVID-19), it is especially important to have access to real-time health information. For instance, it is essential to be informed in the case of a disease outbreak (such as cholera) or a pandemic (COVID-19), or when health centers are out of medicine. In such cases, the use of mobile phone communication allows information to be collected 
and transferred from rural health centers to central hospitals. Although the potential for the application of mobile health education projects (commonly referred to as m-healthEd) is substantial, such projects can easily fail. In addition, there is a risk of creating sophisticated technology with useless tools.

\subsection{Health literacy as social determinant of health}

Health literacy is considered as a critical social determinant of health [22]. Low literacy levels have been shown not only to increase the morbidity rate (higher rate of cervical cancer, for instance) and premature death rate, but also imply poorer management of chronic disease, and lower participation in screening and health promotion [23]. A low level of literacy also has an impact on access to health services (longer hospital stays, inadequate use of drugs, inability to engage in a selfmanagement process, etc.) [24]. High risk groups have also been identified by Public Health France: i.e., the elderly, people with a low level of education, immigrants, the unemployed, and people with low incomes are the most "affected". Indirectly, a high level of literacy contributes to better access to stable and well- paid jobs as well as to quality housing [24]. Furthermore, these people show greater involvement in community life [24]. Improving the level of literacy is a key factor if a population is to stay as healthy as possible[25].

\subsection{The lack of human resources within rural communities in Africa}

Among the main obstacles blocking access to quality healthcare in Africa is the lack of qualified human resources. In rural areas, community health workers, to some extent, take on the role of doctor, nurse and midwife, and in many cases they are undertrained. They require additional and continual training in order to do a better job. Improving the health literacy of community health workers thus offers a more realistic path to rapidly strengthening the healthcare workforce in sub-Saharan African countries and in rural areas in particular.

\subsection{Local languages, Al and mobile technology as healthcare enabler in rural areas}

Africa has multiple languages. According to different estimations and studies, the number ranges between 1,000 and 2,500 local languages [26]. An interesting fact is that nearly half $(48 \%)$ of the countries in SSA have a local language that is spoken by over $50 \%$ of the population [26]. In addition, Africa has at least sixteen of the cross-border languages spoken by more than 150 million people. At institutional level, around 56 local languages are used in administrations and 63 local languages in the judicial systems across the different countries[26]. Unfortunately, almost all the digital tools and services are available only in western languages such as English, French, or others. As a result, thousands of local languages in Africa are excluded from the opportunities offered by the digital world. We could hypothesize that incorporating these local languages into mobile technologies, in particular using Artificial Intelligence (AI) approaches, would help to improve health literacy in rural communities, which would lead to greater accessibility of health services. With this in mind, several projects across the continent have aimed to incorporate local African languages into digital technologies through AI. Thus, the collaboration between various start-ups in Africa, the German International Cooperation 
Agency for Development (GIZ) and Mozilla, for instance, resulted in the launch of projects to develop programs in local languages in 2019. Similarly,languages in 2019. Similarly, in order to increase the availability of more African local language datasets on the internet, the AI for Development (AI4D) program also initiated a project to set up an African Language Dataset the same year. Google also launched an AI research lab in Accra (Ghana) in order to help start-ups to create digital apps and services to solve local problems across the continent. Masakhane is another project which uses Natural Language Processing (NLP) methods to create a network of local language translators across the continent. These ongoing projects illustrate the enthusiasm for AI as a technology inclusion enabler in Africa. However, beyond these opportunities offered by AI, significant threats for vulnerable communities may also arise if appropriate actions are not taken [27]. This is why researchers in collaboration with policymakers need to design technological implementation frameworks to ensure that everyone benefits from such technologies and not just the elite[27].

3.8 Enhancing health literacy in rural areas with mobile technologies

During the 2015 General Assembly of the United Nations (UN), 169 targets and 17 goals were set to be achieved by 2030. These goals, known as the Sustainable Development Goals, were designed to provide a roadmap for peace and prosperity for all by 2030. The health component of these goals (SDG n ${ }^{\circ} 3$ ) aims to promote wellbeing and healthy lives for all. Health literacy, although not explicitly mentioned in the SDGs, is a key step towards achieving the goals [28]. The World Health Organization (WHO) sees a strong correlation between health literacy and several of the SDGs. For example, when the health literacy level is high within a given population, it contributes to improving other SDGs, like the eradication of poverty and hunger, access to quality education and reducing inequality [28]. It also enhances access to health services and quality of care, helping populations to stay healthy and to save money. Likewise, poor health literacy is associated with poor health outcomes, age, income, employment status, and a low level of literacy. This is why the WHO has made literacy a priority initiative to accelerate the achievement of the SDGs[29]. In the African context, special attention must be paid to rural areas if the UN hopes to achieve the SDGs by 2030, as around 656 million people live in such areas (about six in ten people) according to the World Bank[30]. Digital technologies are seen as the driving force of these goals.

\section{Methodology of the systematic literature review}

We used the systematic literature review methodology to conduct our research[31], searching for studies related to the terms "health literacy" and "mobile technology". The following four-step protocol was followed: (1) Database selection; (2) Keyword searches; (3) Study selection; and (4) Data extraction and analysis. We also used a manual search to identify initiatives related to the use of mobile technology to improve health literacy in Africa.

\subsection{Database selection}

A systematic literature review was performed following the preferred reporting items for systematic reviews and meta-analyses (PRISMA) methodology[32]. To perform 
our systematic review, we used the SCOPUS[33] and Google scholar [34] databases as they provide access to Science Technology and Medicine (STM) journal articles and to the references included in these articles, allowing researchers to search both forward and back in time. The search strategy was developed by defining the relevant research question. Without a clear research question, it can be very difficult and time-consuming to identify appropriate resources and to search for relevant evidence. Research questions and inclusion criteria were thus defined according to the PICO (problem, intervention, control and outcomes) framework which informs a literature search and the formulation of research questions[35]. The target issue was the use of "mobile health technology" to improve health literacy in Africa, and rural areas in particular. The intervention involved the description or use of any apps for health literacy, irrespective of whether the corresponding projects were successful or not. All articles describing the use of mobile technology to improve health literacy were included.

\subsection{Keyword search}

We performed the study on 25 November 2020 using Boolean Operators ("AND", "OR") with selected keywords to search through the titles, abstracts and keywords of every published article related to health literacy and mobile technology. The following combinations were used to perform our search in the Scopus database: TITLE- ABS-KEY("health literacy") OR("ALL synonyms of health and literacy") AND ("m-health" OR "Mobile health" OR "mobile technolog*" OR "telemedicine"). For Google scholars, the same combinations were used along with some additional key words: "health literacy" OR "ALL synonyms of health and literacy") AND "mobile health" OR "mobile technology" OR "e-health" AND "Africa" AND "ALL synonyms of rural area".

\subsection{Studies selection}

After performing the Keywords Search, we decided to use only English language publications as such articles are likely to target a wider audience. Further, due to the rapid growth of mobile technology, we limited our literature review to studies published between 2011 and 2020. No author restrictions were imposed.

\subsection{Data extraction}

We exported data related to the "title", "abstract", "keywords", "author", "publication dates" and "country of origin" to a coma separated format. Then we screened the full text of all the publications according to the following criteria:

- studies focused on mobile technology and health literacy; all other studies were excluded;

- studies targeting public health issues in Africa;

- studies related to health literacy and mobile technology in rural areas;

- we carefully analyzed the publications according to the criteria mentioned above, and the selected data were changed to a CSV file format[36]. We excluded all other studies that did not meet the criteria. 

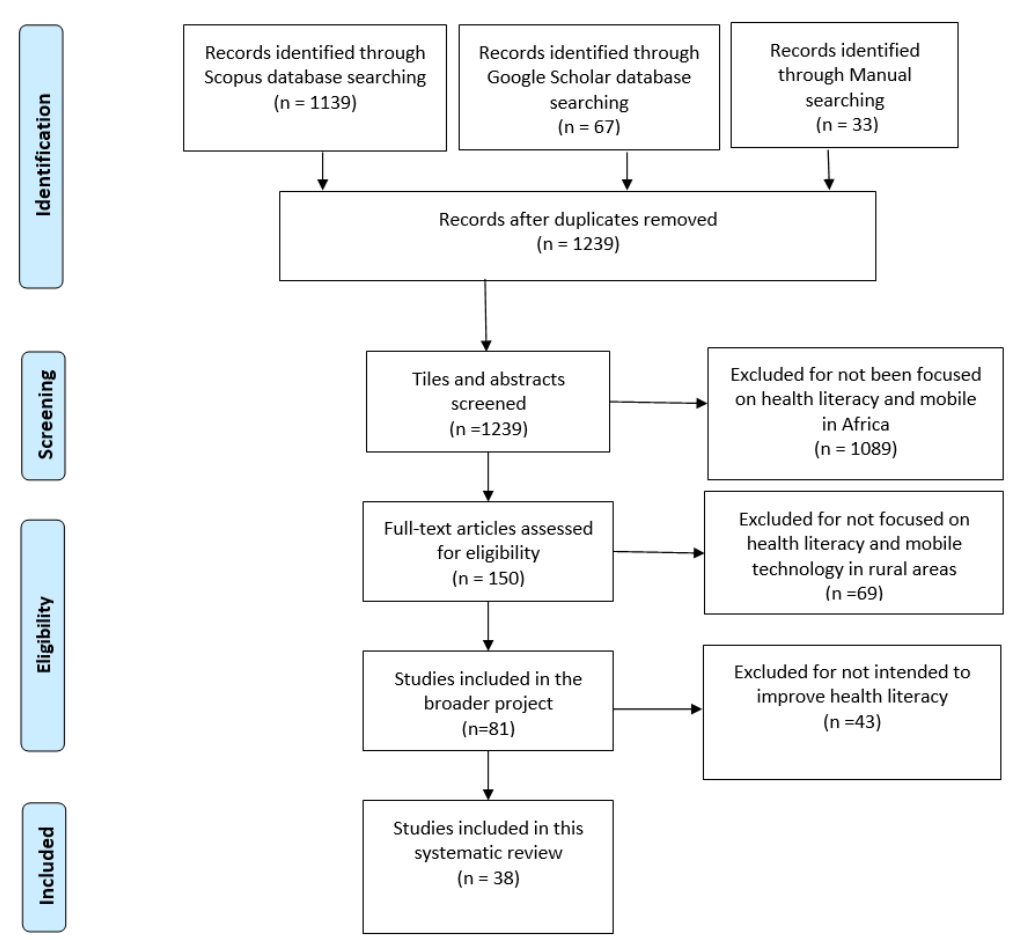

Figure 1 Method used for the systematic literature review

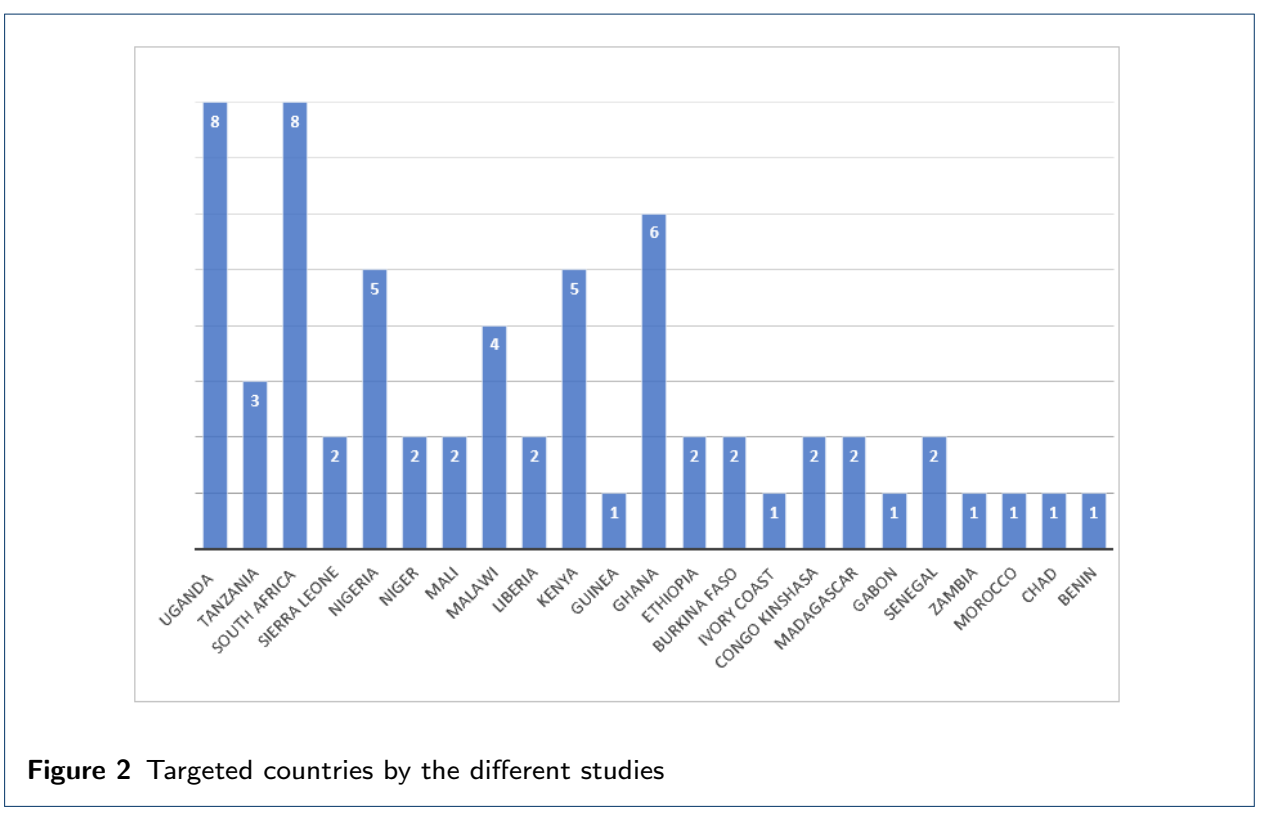




\subsection{Manual search strategy}

We also used a manual search technique to reduce bias by conducting an explicit search for the retrieval of publications that may have fallen through the net in the initial search [37]. The following methods were used to look for references from courses/reviews included, and to look for related articles/articles cited by Scopus and Google Scholar. To optimize and refine the yield of the manual search, we consecutively searched for references to the publications included. We then turned to citation tracking whereby the reviewers track all articles that cite any of the studies included. We also performed a Google database look-up to search for related articles or reports of m-health and related projects not found in Scopus or Google Scholar. Each of the above methods was performed by 2 to 3 independent reviewers. Each article identified was subjected to further scrutiny against the inclusion criteria. Afterwards, the same records were selected from electronic databases, title/abstract and full-text screening.

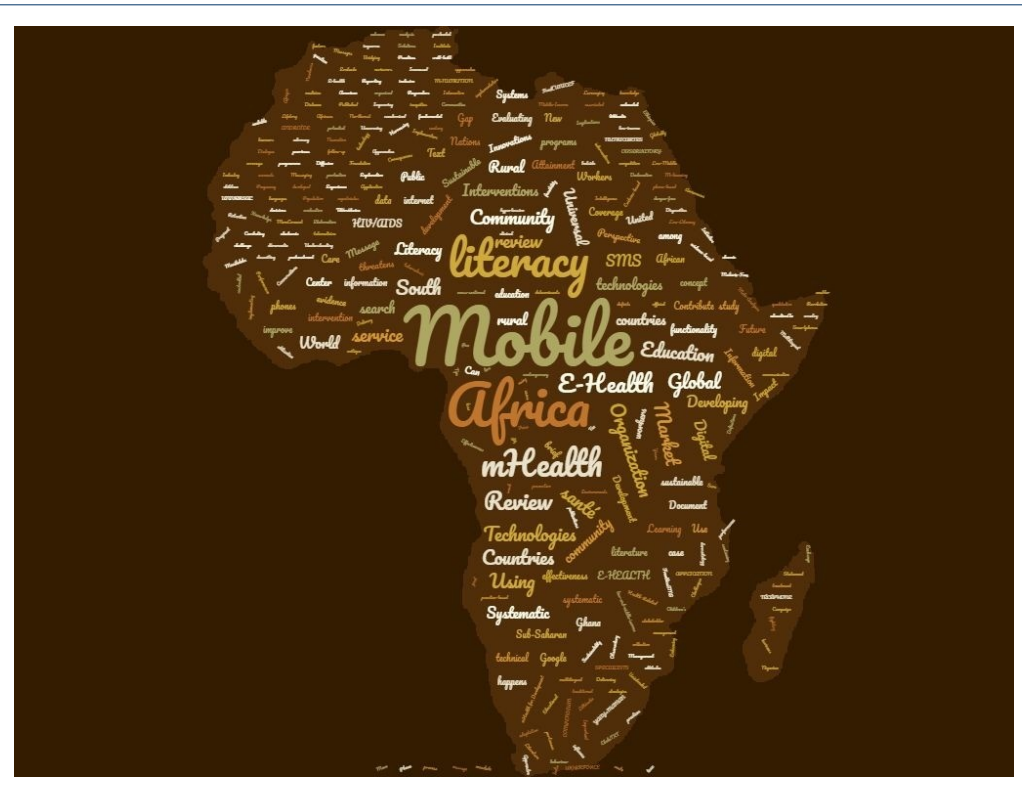

Figure 3 Highlights of the main terms encoutered in the reviewed studies

\section{Results and discussion}

\subsection{Main statistics}

Following our search using the keywords identified, 1,139 publications were found in the Scopus database and 67 with Google Scholar. Once the duplicates were removed, 1,206 articles were left for screening. We screened the titles and abstracts of all 1,206 articles and found that 1,052 studies from the Scopus database and 37 from Google scholar were unrelated to mobile technology and health literacy in Africa. We therefore excluded 1,089 articles in total, leaving 117 for full text screening. We then screened the full text of the 117 articles and finally selected just 48 studies. With further screening, we found that only 5 were related to health literacy and mobile technology in rural areas. Further analysis of these 5 studies indicated that they were not specifically intended to improve health literacy in 
a rural area or communities. Our manual look-up yielded $33 \mathrm{~m}$-health initiatives related to improving health literacy in Africa. In total, 38 studies were included in the literature review. Figure 1 summarizes the method used and the findings.

\subsection{Related topics}

In addition to keywords in the abstract, word clouds [38] were used to depict the main terms encountered from both the titles and the abstracts of the studies retrieved. As shown in Figure 3, the words "mobile", "Africa", "literacy", "health" and e-health were the most prominent terms. In other words, these terms could also be used to track the studies related to our review.

Table 1: Included studies and the technology used.

\begin{tabular}{|c|c|c|c|}
\hline $\begin{array}{l}\text { m-health } \\
\text { initiative }\end{array}$ & Country & Technology used & $\begin{array}{l}\text { Sector of in- } \\
\text { tervention }\end{array}$ \\
\hline $\begin{array}{l}\text { Google } \\
\text { SMS } \\
\text { Health } \\
\text { Tips } \\
\end{array}$ & Uganda & $\begin{array}{l}\text { SMS based service that allows users to access healthcare- } \\
\text { related information [39]. }\end{array}$ & General Health \\
\hline $\begin{array}{l}\text { MTN } \\
\text { Kick Out } \\
\text { Malaria }\end{array}$ & $\begin{array}{l}\text { South } \\
\text { Africa }\end{array}$ & $\begin{array}{l}\text { SMS based quiz designed to educate the general public } \\
\text { about malaria [40]. }\end{array}$ & General Health \\
\hline $\begin{array}{l}\text { Freedom } \\
\text { HIV/AIDS }\end{array}$ & Kenya & $\begin{array}{l}\text { Mobile-based games designed to create HIV/AIDS aware- } \\
\text { ness. }\end{array}$ & $\begin{array}{l}\text { Sexual reproduc- } \\
\text { tive health (incl. } \\
\text { HIV/AIDS) }\end{array}$ \\
\hline $\begin{array}{l}\text { Project } \\
\text { Masiluleke }\end{array}$ & $\begin{array}{l}\text { South } \\
\text { Africa }\end{array}$ & $\begin{array}{l}\text { Use of SMS messages to provide referral to the National } \\
\text { AIDS Helpline. }\end{array}$ & $\begin{array}{l}\text { Sexual reproduc- } \\
\text { tive health (incl. } \\
\text { HIV/AIDS) }\end{array}$ \\
\hline $\begin{array}{l}\text { Text to } \\
\text { Change }\end{array}$ & $\begin{array}{l}\text { Kenya, } \\
\text { Uganda }\end{array}$ & $\begin{array}{l}\text { General HIV/AIDS quiz using SMS to create HIV/AIDS } \\
\text { and public health awareness [41]. }\end{array}$ & $\begin{array}{l}\text { Sexual reproduc- } \\
\text { tive health (incl. } \\
\text { HIV/AIDS ) }\end{array}$ \\
\hline $\begin{array}{l}\text { Young } \\
\text { Africa Live }\end{array}$ & $\begin{array}{l}\text { South } \\
\text { Africa }\end{array}$ & $\begin{array}{l}\text { Mobile entertainment portal designed to engage youth on } \\
\text { topics related to sexual health[42]. }\end{array}$ & $\begin{array}{l}\text { Sexual reproduc- } \\
\text { tive health (incl. } \\
\text { HIV/AIDS) }\end{array}$ \\
\hline M4RH & $\begin{array}{l}\text { Kenya, } \\
\text { Tanzania }\end{array}$ & $\begin{array}{l}\text { Automated SMS based system that provides access to family } \\
\text { planning information [43]. }\end{array}$ & $\begin{array}{l}\text { Sexual reproduc- } \\
\text { tive health (incl. } \\
\text { HIV/AIDS) }\end{array}$ \\
\hline $\begin{array}{l}\text { MoTeCH } \\
\text { Mobile } \\
\text { Midwife }\end{array}$ & Ghana & $\begin{array}{l}\text { Java-based information service that delivers time-specific } \\
\text { voice or text messages to pregnant mothers and their part- } \\
\text { ners and families before and after childbirth[44]. }\end{array}$ & $\begin{array}{l}\text { Maternal child } \\
\text { health. }\end{array}$ \\
\hline Allo Laafia & $\begin{array}{l}\text { Burkina } \\
\text { Faso }\end{array}$ & $\begin{array}{l}\text { Use of SMS and voice messaging to send personalized advice } \\
\text { on various health issues [45]. }\end{array}$ & $\begin{array}{l}\text { Maternal child } \\
\text { health. }\end{array}$ \\
\hline Polly & Guinea & $\begin{array}{l}\text { Use of voice messaging to send information related to Ebola } \\
\text { epidemic [46]. }\end{array}$ & Ebola \\
\hline $\begin{array}{l}\text { SMS for ed- } \\
\text { ucation and } \\
\text { promotion }\end{array}$ & $\begin{array}{l}\text { Low } \\
\text { income } \\
\text { countries }\end{array}$ & $\begin{array}{l}\text { Mobile health literacy to improve health outcomes in low/ } \\
\text { middle income countries (Low income Book) }[47] \text {. }\end{array}$ & General Health \\
\hline $\begin{array}{l}\text { SMS for ed- } \\
\text { ucation and } \\
\text { promotion }\end{array}$ & Liberia & $\begin{array}{l}\text { Collection using SMS text messaging in areas of low network } \\
\text { coverage from low-literacy provider [48]. }\end{array}$ & General Health \\
\hline WeChat & Niger & $\begin{array}{l}\text { Use of official WeChat (social medial) accounts to im- } \\
\text { prove malaria health literacy among Chinese expatriates in } \\
\text { Niger:an intervention study[49]. }\end{array}$ & Malaria \\
\hline $\begin{array}{l}\text { SMS for ed- } \\
\text { ucation }\end{array}$ & $\begin{array}{l}\text { South } \\
\text { Africa / }\end{array}$ & $\begin{array}{l}\text { SMS messaging systems to improve tuberculosis treatment } \\
{[50] \text {. }}\end{array}$ & $\begin{array}{l}\text { Tuberculosis } \\
\text { (TB) }\end{array}$ \\
\hline $\begin{array}{l}\text { SMS for ed- } \\
\text { ucation }\end{array}$ & $\begin{array}{l}\text { South } \\
\text { Africa }\end{array}$ & $\begin{array}{l}\text { SMS messaging systems to improve hypertension knowledge } \\
\text { for deaf South Africans[51]. }\end{array}$ & Hypertension \\
\hline
\end{tabular}

\subsection{Overview of the key m-healthEd initiatives}

As shown in Table 1 and Table 2, many m-health initiatives have emerged to address the need for health information in Africa. Most of the mobile solutions provide 
information on sexual and reproductive health (including HIV/AIDS), maternal and child health, and general health issues.

\subsection{Project Masiluleke}

The Masiluleke Project uses mobile technology to persuade South Africans to get tested for HIV. One million text messages saying" Please call me" are sent across South Africa every day to encourage people to go for an HIV test and seek treatment [52]. Written in regional languages, these messages direct users to the national AIDS hotline. Once a patient is online, he/she is informed about HIV testing services and given an address to go for a test. In a country where nearly $20.4 \%$ of the population is living with HIV, knowing your HIV status is essential [53]. Project partners include Nokia and the South African National AIDS Service Hotline.

Table 2: Studies included and the technology used

\begin{tabular}{|c|c|c|}
\hline m-health initiative & Country & Technology used \\
\hline $\begin{array}{l}\text { African Medical and } \\
\text { Research Foundation } \\
\text { (AMREF): distance } \\
\text { learning for nurses }\end{array}$ & Kenya, Uganda & $\begin{array}{l}\text { A mobile website designed to give nurses access to informa- } \\
\text { tion about AR treatment protocols, and piloting the use of } \\
\text { mobile based peer-to-peer learning for nursing students [54]. }\end{array}$ \\
\hline $\begin{array}{lr}\text { eMOCHA: } & \text { com- } \\
\text { prehensive } & \text { mobile } \\
\text { open-source } & \text { e-health } \\
\text { application } & \end{array}$ & Uganda & $\begin{array}{l}\text { The eMOCHA application provides multi-media courses and } \\
\text { lectures (recorded in MP4 format), followed by quizzes to } \\
\text { test users knowledge of the information. It is also used to } \\
\text { collect data and as a communication tool for health workers } \\
\text { [55]. }\end{array}$ \\
\hline FrontlineSMS: Learn & Uganda & $\begin{array}{l}\text { FrontlineSMS: uses free open-source software to support } \\
\text { knowledge retention for trained healthcare workers. JH- } \\
\text { PIEGO also pilots the platform to prompt SMS based re- } \\
\text { sponses and quizzes on family planning modules after train- } \\
\text { ing in Uganda[55]. }\end{array}$ \\
\hline $\begin{array}{l}\text { Health Education and } \\
\text { Training in Africa } \\
\text { (HEAT) program }\end{array}$ & Ethiopia & $\begin{array}{l}\text { Uses an online knowledge bank of learning resources that can } \\
\text { be freely accessed by any individual, organization, training } \\
\text { community, healthcare worker, and global health institution, } \\
\text { as well as exploring the use of mLearning for distribution[56]. }\end{array}$ \\
\hline $\begin{array}{l}\text { Millennium Villages } \\
\text { Project (MVP): life- } \\
\text { long learning for } \\
\text { health workers }\end{array}$ & $\begin{array}{l}\text { Ghana, Kenya, } \\
\text { Uganda, Tanzania, } \\
\text { Malawi }\end{array}$ & $\begin{array}{l}\text { ChildCount }+ \text { is a mobile technology solution for an SMS- } \\
\text { based mobile phone data collection and support on a } \\
\text { RapidSMS platform[57]. }\end{array}$ \\
\hline $\begin{array}{l}\text { AED-SATELLIFE: } \\
\text { Mobile Health In- } \\
\text { formation System } \\
(\text { MHIS) }\end{array}$ & South Africa & $\begin{array}{l}\text { Provides health workers with locally relevant, reliable and } \\
\text { accurate clinical information at the point of care through } \\
\text { smartphones pre-loaded with a library of pertinent resources } \\
\text { [58]. }\end{array}$ \\
\hline HealthWiki & Tanzania & $\begin{array}{l}\text { Allows users to browse eight free volumes of health informa- } \\
\text { tion on a range of topics via cell phones or computers[59]. }\end{array}$ \\
\hline EbolaTXT & $\begin{array}{l}\text { Sierra Leone, Mali, } \\
\text { Ghana, Uganda, } \\
\text { Malawi }\end{array}$ & $\begin{array}{l}\text { Uses SMS for social mobilization and reporting on the Ebola } \\
\text { outbreak [60]. }\end{array}$ \\
\hline iDEA & Nigeria & $\begin{array}{l}\text { Provides health workers with mobile-based video instruc- } \\
\text { tions and reference materials [61]. }\end{array}$ \\
\hline OPPIAMOBILE & $\begin{array}{l}\text { Ethiopia, Nigeria, } \\
\text { Ghana }\end{array}$ & $\begin{array}{l}\text { Mobile phone platform that provides the complete national } \\
\text { health extension worker (HEW) training materials [62]. }\end{array}$ \\
\hline U-Report & $\begin{array}{l}\text { Nigeria, Liberia } \\
\text { Sierra Leone }\end{array}$ & $\begin{array}{l}\text { Uses SMS RapidPro to send messages about the needs of } \\
\text { young people and provide them with Ebola-related informa- } \\
\text { tion [63]. }\end{array}$ \\
\hline $\begin{array}{l}\text { ALERTE } \\
\text { SANTÉ }\end{array}$ & Ivory Coast & $\begin{array}{l}\text { Aims to inform, raise awareness and give advice on good } \\
\text { health practices via SMS and USSD. Provides information, } \\
\text { awareness-raising and advisory service in the field of health } \\
\text { for the whole population. }\end{array}$ \\
\hline VULA MOBILE & South Africa & $\begin{array}{l}\text { Vula is an Android and iOS app that facilitates referrals be- } \\
\text { tween primary healthcare workers and medical specialists to } \\
\text { improve the care of patients in rural, remote and underserved } \\
\text { areas [64]. }\end{array}$ \\
\hline
\end{tabular}




\begin{tabular}{|c|c|c|}
\hline Service $3-2-1$ & $\begin{array}{lr}\text { Congo } & \text { Kinshasa } \\
\text { Ghana Madagascar } \\
\text { Malawi } & \text { Nigeria } \\
\text { Uganda } & \end{array}$ & $\begin{array}{l}\text { Provides access to important mobile health information } \\
\text { (IVR/audio) in the local language[65]. }\end{array}$ \\
\hline Zero Mothers Die & $\begin{array}{l}\text { Ghana, Mali, } \\
\text { Gabon, Nigeria }\end{array}$ & $\begin{array}{l}\text { Uses mobile technology to increase access to pregnancy in- } \\
\text { formation and emergency care [66]. }\end{array}$ \\
\hline MomConnect & South Africa & $\begin{array}{l}\text { Every pregnant woman in South Africa can register through } \\
\text { this platform to receive free, informative, stage-based mes- } \\
\text { saging via SMS or WhatsApp for her pregnancy up to the } \\
\text { second year of the baby's life [67]. }\end{array}$ \\
\hline MY Virtual Planning & $\begin{array}{l}\text { Democratic Repub- } \\
\text { lic of Congo }\end{array}$ & $\begin{array}{l}\text { ePrevents unwanted pregnancies by educating young people } \\
\text { about sexuality, and facilitating access and effective use of } \\
\text { modern contraceptives thanks to digital technology [68]. }\end{array}$ \\
\hline YAAY.SN ${ }^{[1]}$ & Senegal & $\begin{array}{l}\text { This educational tool offers everyday decision-making re- } \\
\text { sources for mothers in key areas like healthcare, education } \\
\text { and careers/entrepreneurship[69]. }\end{array}$ \\
\hline m-NUTRITION & Malawi, Zambia & $\begin{array}{l}\text { Contributes to preventing and reducing chronic malnutrition } \\
\text { through access to nutritional information via mobile technol- } \\
\text { ogy [70]. }\end{array}$ \\
\hline TBIBCOM & Morocco & $\begin{array}{l}\text { Offers a support service for patients suffering from chronic } \\
\text { diseases via a "patient" platform, available online and on } \\
\text { cell phones, containing a therapeutic education module and } \\
\text { a telemonitoring module. It offers short educational videos } \\
\text { in Arabic dialects that are easy to understand, as well as } \\
\text { educational games to inform and ensure that patients ad- } \\
\text { here to their treatment, and to consolidate and verify their } \\
\text { knowledge[71]. }\end{array}$ \\
\hline Apprendre A Vivre ${ }^{[2]}$ & Senegal & $\begin{array}{l}\text { Gives access to accurate information regarding sexual and } \\
\text { reproductive health and rights[72]. }\end{array}$ \\
\hline $\begin{array}{l}\text { THE NUTRI- } \\
\text { CARTES application } \\
\text { game on android } \\
\text { phone }\end{array}$ & $\begin{array}{l}\text { Madagascar, Burk- } \\
\text { ina Faso, Chad, } \\
\text { Niger }\end{array}$ & $\begin{array}{l}\text { Gives nutritional information to families for children under } \\
\text { the age of } 5 \text { via a game made up of photo cards that represent } \\
\text { foods found in the market and a mat with } 4 \text { colors: Red for } \\
\text { Construction foods (proteins), Yellow for Energy foods (car- } \\
\text { bohydrates, lipids), Green for Protection foods (vitamins, } \\
\text { micro-nutrients) and Blue for water[73]. }\end{array}$ \\
\hline ASCA BENIN & Benin & $\begin{array}{l}\text { Uses SMS to send monthly messages to patients being } \\
\text { treated for mental illnesses to remind them of their appoint- } \\
\text { ment day at the health centers[74]. }\end{array}$ \\
\hline
\end{tabular}

\subsection{Mobile technology for reproductive health $(\mathrm{m} 4 \mathrm{RH})$}

In 2010, Family Health International's (FHI 360) mobile technology for health $(\mathrm{m} 4 \mathrm{RH})$ project launched a series of SMS and short messages on eight family planning methods for mobile phone users in Kenya and Tanzania [75]. This nine- month pilot project began in Nairobi in collaboration with nine of the city's health facilities, including two private clinics run by Marie Stopes International/Kenya and Family Health Options Kenya, the Kenyan partner of the International Family Planning Foundation. The messages were written using information from evidence-based sources, including the WHO's guide to family planning. They met the 160-character short text limits and were rigorously tested to facilitate end-user understanding. The $\mathrm{m} 4 \mathrm{RH}$ project system also gives information on service delivery so users can easily locate health facilities that offer the family planning methods of their choice. The mobile access codes that customers must enter to access the m4RH system are displayed on posters, mini cards and brochures.

${ }^{[1]}$ YAAY $=$ Mom in WOLOF, main language in Senegal)

${ }^{[2]}$ Learning to live 


\subsection{MoTeCH MobileMidwife}

This project was initiated by the largest private development fund agency - the Bill and Melinda Gates Foundation. Motech was launched in Ghana in 2010 [76]. Designed for pregnant women and mothers of children under one year of age, it provides two applications that are automatic remote voice message systems. Each week, depending on the stage of the pregnancy or the age of the baby, the system sends a voice message of less than two minutes in the local language to the number stored in the Motech database. The Service is free in Ghana.

\subsection{Polly}

Polly is a set of applications that spread virally and disseminate information[46]. It has three main options. The first application is a Game option designed to attract new users and motivate them to interact with the system through entertainment. The second Spread application targets members of the general public to spread Ebola messages as many times as possible. The last application is Polly/Browse, designed for community healthcare workers needing occasional reminders and the possibility to send messages when needed.

\subsection{HealthWiki}

HealthWiki provides underserved individuals and communities with free access to much needed health information in a user-friendly, culturally-sensitive, heavily- illustrated, language-specific format, tailored for use by individuals and community health workers and other community leaders. Available in their own languages, and freely available in mobile friendly online format, the easy-to-use and practical information helps to empower readers to take charge of their own healthcare. It allows users to browse eight free volumes of health information on a range of topics via mobile phones or computers.

\subsection{Service 3-2-1}

The 3-2-1 Service is a Viamo solution [65] which provides access to important mobile health information (IVR/audio) in the local language. The technology uses IVR, compared to SMS, and offers pragmatic advantages to address the challenges of illiteracy and overcome the limitations of special characters. It allows messages to be delivered in a voice/accent that is understandable in the local language.

\subsection{Discussion}

As stated earlier, the initial literature review search identified 1,206 articles from the two databases. However, only 5 articles were included following the full text review. Once we started the full-text review, we focused our analysis on publications that address the use of mobile technology to improve health literacy in rural areas of Africa. From the 1,206 publications, we only detected $5(0.41 \%)$ papers related to mobile technology and health literacy in rural areas of Africa. The other 1,201 articles reviewed (99.58 \%) did not cover improvement of health literacy in African rural areas. This highlights the need to conduct more studies geared to this topic. Following a manual search, we found a further 33 m-health initiatives related to improving health literacy in Africa. Thus, a total of 38 studies were included in our literature review. 
After analysis of the selected studies, our findings suggest that, for most of the projects, while the technology developed does address people with low literacy skills, very few m-health solutions ("Polly" in Guinea and HealthWiki) take local languages into account in the design and development of their technology. We also found that the majority of m-health education projects funded do not have proven financial sustainability models. As a result, most of the projects cannot survive after proof of concept.

\section{Implementation of $\mathbf{m}$-health project in Africa: opportunities and challenges}

\section{$6.1 \mathrm{~m}$-health in Africa}

In Africa, the widespread craze for mobile phones is transforming healthcare systems by making mobile health applications a major tool for improving the health of Africans. Better use of m-health can significantly help overcome barriers and improve health outcomes. m-health has the potential to overcome the following hurdles in Africa [59]:

- disparities in access to health services

- inadequate national health infrastructure

- poor human resources

- the high cost of access to health and insufficient financial resources.

In a global survey, WHO found that $83 \%$ of member states implemented m- health technologies [59]. Implanted m-health can be divided into 14 categories: (1) mobile telemedicine, (2) health surveys and data collection, (3) decision-support systems, (4) surveillance, (5) patient monitoring, (6) treatment compliance, (7) mobile patient records, (8) appointment reminders, (9) toll-free emergency telephone services, (10) health call centers, (11) managing emergencies and disasters, (12) health awareness-raising, (13) community mobilization and health promotion, and (14) access to information. For the purposes of this study, we reviewed the use of mobile health technologies to foster health literacy through health promotion and training, and easier access to information. The m-health landscape in Africa is mainly made up of mobile phones, tablets, mobile applications and wireless medical devices, although this scenario is constantly changing. Factors that contribute to its development include: the rapid spread of mobile technologies and applications, increased potential for interoperability and integration between m-health and e-health interventions, as well as continued growth in mobile network coverage. Many believe that m-health can transform healthcare systems in Africa by offering new ways of accessing and delivering healthcare services.

\subsection{Opportunities}

To make health systems in developing countries more efficient in the face of chronic disease, understaffing and health information deficits, new solutions to complex health issues include access to health information, the development of new medical processes, improvements to existing tools, and mobile health offers. This is an opportunity for Sub- Saharan African countries where the deficit of health workers is projected to rise to 12.9 million skilled health professionals by 2035 [77]. As a result, access to medical facilities, care and health information will be more difficult for over half the African population living in rural areas. The development of mobile 
health programs as shown in Table 1 and Table 2 offer effective solutions to these challenges. Mobile healthcare can reduce the gaps and provide greater access to medical information and healthcare on the continent. The rapid mobile penetration being experienced in sub-Saharan Africa is the main pillar of this transformation. Currently, mobile phones are used as tools to improve and speed up access to healthcare systems in rural areas [78], and have been used in healthcare workers' training, prevention and access to health information, remote consultations and patient monitoring [79]. Most m-health projects are still in the "pilot" phase, however. For the benefits to be more visible, it is important to move beyond the "pilot" phase and to scale-up apparently effective and replicable projects [55]. However, for this dynamic to be sustainable and inclusive, the technology must be designed for and with caregivers and citizens in order to respond to the priorities of national health policies. It should also be developed and financed from a long-term perspective. The involvement of African governments, the commitment of firms in the digital sector, the vigilance of citizens and the coordination of actors are all essential factors. From the descriptions and fields of application given above, we can affirm that the adoption and use of mobile phones has obvious benefits for improving the health literacy of populations living in rural areas. For developing countries, especially Africa, this technology requires the direct involvement of populations. Benefits for the African healthcare system include:

- Enhancing the inclusion of rural communities in healthcare services through the use of local languages;

- Fostering information accessibility through the availability of low-cost technology like mobile phones;

- Improving public health surveillance by raising awareness and developing campaigns conducted in local languages.

\subsection{Challenges}

In general, the lack of sustainable infrastructures, whether in terms of finance, health or IT, hampers the implementation of a real public health strategy in Africa. Most African countries have still not reached the targets set out in the Abuja Declaration (2001), in which governments agreed to allocate $15 \%$ of their national budget to health [80]. From our perspective, the three main challenges to m-healthEd projects in rural areas of Africa are described below. The first challenge is that, despite the above-mentioned explosion in the rate of access to mobile telephony, SSA remains the region of the world where internet is least used. A study conducted by the University of Oxford established a global map which identified Asia as having 1.24 billion users ( $46 \%$ or nearly half of the world's internet users)[81]. In contrast, SSA seems to have been left off the map. The continent is virtually disconnected from the internet and the various cultural, economic and political options and activities it offers. Less than $10 \%$ of the population is connected [82].

The second challenge is that the internet quality available is very poor and under political control. As a result, the inadequate internet equipment prevents Africa from accessing digitized satellite data. While there is a desire to set up an e-health system, the continent's weaknesses restrict practitioners' access to open archives on the pathologies they follow medically. Poor internet quality can thus seriously hamper m-health penetration in Africa. 
The third challenge is that the equipment supporting connectivity (electricity, computer circuits, etc.) is unavailable, or unreliable when it exists. Africa is an "eternal night society" continent as it is under-electrified. In addition to this underelectrification, extremely frequent and untimely electricity cuts impede both economic activity and the health sector. There are extensive power cuts in almost every country in West Africa. Most power plants and electricity transmission networks were built in the 1950s and 1960s, but given the lack of investment and maintenance, the infrastructure is failing. These remarks can be extended to the entire continent, where the rationing imposed in the sector, even in the African capitals, restricts the development of m-health which requires reliable computer support networks and a stable energy sector.

\section{Main implications of the study}

\subsection{Promote collaboration between actors and stakeholders}

Stakeholders should establish a systematic approach when it comes to implementing m-health projects in Africa[83]. Strengthening skills through continuous training programs for community health workers is essential to fight against health literacy in rural areas, for example. Stakeholders include governments, healthcare institutions, universities, content creators, mobile operators, device makers, NGOs, philanthropists and investors. All must work together closely as they play their respective roles in the successful delivery of m-health projects.

\subsection{The need to scale-up m-health solutions}

For the rapid and large-scale deployment of m-health technologies, coordinated and synchronized approaches are needed [84]. m-health project goals must be ambitious, with emphasis on the rapid deployment of the most promising innovations within the framework of national health strategies and health workforce development plans. In selecting projects that can be scaled up, attention should be paid to all the pilot projects according to their likelihood of a quick ramp up, rather than building large portfolios of pilot project programs.

\subsection{The need to develop an inclusive m-health solution}

For m-health projects to be inclusive, they should be designed with all local needs and realities taken into consideration. Local languages and culture need to be included to ensure that the realities of rural communities are fully integrated [85]. m-health technology content must also be developed with the close collaboration of local experts so as to take local needs into account [86]. Extreme poverty and the lack of internet and health infrastructures are the main barriers to the implementation of m-health in Africa, particularly in rural areas. It is therefore important to develop technological solutions in line with the local situation.

\subsection{The need for a financial sustainability model}

The majority of m-health education projects that are funded do not have proven financial sustainability models, so funding models need to be developed which ensure the sustainability of the projects after the proof of concept[55]. It is likely that authorities or training centers are willing to pay for m-health applications intended 
for healthcare workers, so they must have proof of the effectiveness of the services offered. Applications that reduce the time or cost of training healthcare workers, for example, will logically be welcomed. Some applications may be aimed at students interested in supporting their own learning and certification. Mobile operators or device manufacturers may also be willing to offer free mobile healthcare educationrelated services or devices to people living in rural areas. With this in mind, they could facilitate health information campaigns with free or low-cost rates as part of a larger contract with government or private sector institutions, or part of their social responsibility programs.

\section{Conclusions, limitations and future research}

Between 2011 and 2020, 1,206 different publications related to health literacy and mobile technology were available in SCOPUS and Google Scholar databases. In addition, we also found 33 related projects through a manual search. All these studies confirm the significant role that mobile technologies can play in improving health literacy. However, most studies on mobile technologies have been conducted at national or continent level. The 38 studies that we found related to Africa provide a comprehensive overview of mobile technologies in health systems in African countries. Unfortunately, we did not find a specific framework addressing the use of mobile technologies to improve health literacy in rural areas. Our review findings suggest that despite the enthusiasm regarding mobile health technologies in Africa in recent years, very few prior studies have examined the contribution of such technologies to improving health literacy in rural areas. The current literature review also suggests the need for more precise studies on the integration of local languages into mobile technologies to improve health literacy. Finally, our study highlights the important role that health literacy plays in achieving the 2030 SDGs. Mobile health technologies can enable patients in rural areas, who generally have limited access to healthcare, to benefit from continual care, even after leaving health facilities. Unfortunately, many successful pilot projects in the field of m-health are never extended to programs at regional or national level. Creating large-scale and sustainable $\mathrm{m}$-health interventions requires collaboration between different stakeholders [87]. Despite these challenges, m-health technologies have a key role to play in enhancing health literacy and improving access to healthcare in rural areas[78]. To make this happen, the establishment of a clear and specific mobile health framework for rural areas must be a priority for governments and NGOs working on healthcare issues on the African continent. However, the study has some limitations as we only used two databases to conduct our systematic literature review. This meant we could not find additional studies indexed by other databases. Future studies should thus consider using a combination of additional databases, including the Web Of Science, and even gray literature, which could potentially give access to projects conducted by NGOs. Regarding future work, our next study will focus on designing a mobile-based implementation framework dedicated to low-literate empowerment for people in rural areas to help them be actors in their own healthcare. The potential framework should take technology acceptance issues by the end users into account [88]. 
Competing interests

The authors declare that they have no competing interests.

\section{Author's contributions}

IO and GD conceived the study. GD, BMS and RB validated the methodological approach and the research equations. All the authors analysed the results. 10 wrote the first draft of the manuscript. GD improved the manuscript in English. All authors participated in the final review of the manuscript, corrected and approved the manuscript for submission.

\section{Acknowledgements}

IO is supported with a PhD scholarship from the Government of Burkina Faso. The study is also supported by the PATIENT-Covid19 project. Thus we would like to thank the Agence Universitaire de la Francophonie (AUF) and the Covid mission of University of Bordeaux.

Author details

${ }^{1}$ ESI Université Nazi Boni, Bobo Dioulasso, 01 BP : 1091 Bobo Dioulasso, Burkina Faso. ${ }^{2}$ Center for Advanced Studies Eurac Research, Drususallee, 139100 Bozen/Bolzano, Italy. ${ }^{3}$ Team ERIAS, BPH Health INSERM 1219, Univ. Bordeaux, F-33000, Bordeaux, France. ${ }^{4}$ INRIA SISTM, BPH Research Center, Univ. Bordeaux, F-33000, Bordeaux, France.

\section{References}

1. Diallo, B.: Telecom: 660 million Africans will be equipped with a smartphone in 2020! (2018). https://www . afrikatech.com/start-business/telecom-660-million-africans-will-equipped-smartphone-2020/ Accessed 2021-02-08

2. Haenssgen, M.J., Ariana, P.: The Social Implications of Technology Diffusion: Uncovering the Unintended Consequences of People's Health-Related Mobile Phone Use in Rural India and China. World Development 94, 286-304 (2017). doi:10.1016/j.worlddev.2017.01.014. Accessed 2020-10-14

3. Botha, A., Booi, V.: mhealth implementation in south africa, 1-13 (2016). doi:10.1109/ISTAFRICA.2016.7530667

4. Forecast, M.D.: MEA Mobile health Market Industry report 2019-2025 (2020). https : //www.marketdataforecast.com/market-reports/middle-east-and-africa-mobile-health-market Accessed 2020-11-26

5. Ownby, R.L., Acevedo, A., Waldrop-Valverde, D.: Enhancing the Impact of Mobile Health Literacy Interventions to Reduce Health Disparities. Quarterly review of distance education 20(1), 15-34 (2019). Accessed 2020-07-02

6. Scheil-Adlung, X.: Global evidence on inequities in rural health protection : New data on rural deficits in health coverage for 174 countries. International Labour Office (2015). https://ww . social-protection.org/gimi/gess/RessourcePDF . action?ressource. ressourceId=51297

7. WHO: World Health Organization| Track 2: Health literacy and health behaviour. Publisher: World Health Organization (2009). https://www . who. int/healthpromotion/conferences/7gchp/track2/en/ Accessed 2021-01-04

8. site of the U.S. Health Resources \& Services Administration, O.W.: Health Literacy. Last Modified: 2019-08-13T11:39-04:00 (2017). https://www.hrsa.gov/about/organization/bureaus/ohe/health-literacy/index.html Accessed 2021-01-24

9. World-Bank: World Bank Country and Lending Groups. https://datahelpdesk.worldbank.org/ knowledgebase/articles/906519-world-bank-country-and-lending-groups Accessed 2021-02-08

10. GSMA: The Mobile Economy Sub-Saharan Africa (2019). https://data.gsmaintelligence.com/api-web/ v2/research-file-download?id=45121567\&file=2794-160719-ME-SSA.pdf Accessed 2021-01-03

11. Rotondi, V., Kashyap, R., Pesando, L.M., Spinelli, S., Billari, F.C.: Leveraging mobile phones to attain sustainable development. Proceedings of the National Academy of Sciences of the United States of America 117(24), 13413-13420 (2020). doi:10.1073/pnas.1909326117

12. Muthiah, G., Prashant, S., Jhunjhunwala, A.: A Review on Challenges in implementing mobile phone based data collection in Developing countries. The Journal of Health Informatics in Developing Countries 5, 366-374 (2011)

13. Organization|, W.H.: The mandate for health literacy. Publisher: World Health Organization (2016). http://www . who.int/healthpromotion/conferences/9gchp/health-literacy/en/ Accessed 2021-01-04

14. Wickham, C.: Can technology improve health literacy? 03. doi:10.4172/2161-0509.1000e114

15. Nutbeam, D.: Health literacy as a public health goal: a challenge for contemporary health education and communication strategies into the 21st century. Health Promotion International 15(3), 259-267 (2000). doi:10.1093/heapro/15.3.259. Accessed 2021-01-04

16. Shiferaw, K.B., Tilahun, B.C., Endehabtu, B.F., Gullslett, M.K., Mengiste, S.A.: E-health literacy and associated factors among chronic patients in a low-income country: a cross-sectional survey. BMC Medical Informatics and Decision Making 20(1), 181 (2020). doi:10.1186/s12911-020-01202-1. Accessed 2021-01-07

17. PAHO: Pan American Health Organization - eHealth PAHO/WHO. https://www . paho.org/ict4health/index .php?option=com_content\&view=article\&id=80: components\&Itemid=0\&lang=en Accessed 2021-01-04

18. Goel, S., Bhatnagar, N., Sharma, D., Singh, A.: Bridging the Human Resource Gap in Primary Health Care Delivery Systems of Developing Countries With mHealth: Narrative Literature Review. JMIR mHealth and uHealth 1(2), 25 (2013). doi:10.2196/mhealth.2688. Company: JMIR mHealth and uHealth Distributor: JMIR mHealth and uHealth Institution: JMIR mHealth and uHealth Label: JMIR mHealth and uHealth Publisher: JMIR Publications Inc., Toronto, Canada. Accessed 2021-01-04 
19. Ryu, S.: Book review: mHealth: New horizons for health through mobile technologies: Based on the findings of the second global survey on eHealth (global observatory for eHealth series, volume 3) 18(3), 231-233. doi:10.4258/hir.2012.18.3.231. Accessed 2021-02-09

20. Foundation, U.N.: mHealth for Development (2009). http://www.globalproblems-globalsolutions-files . org/unf_website/assets/publications/technology/mhealth/mHealth_for_Development_full.pdf

21. Laura Silver,Courtney Johnson: Basic Mobile Phones More Common than Smartphones in sub-Saharan Africa. https://www. pewresearch.org/global/2018/10/09/ majorities-in-sub-saharan-africa-own-mobile-phones-but-smartphone-adoption-is-modest/ Accessed 2021-02-09

22. Rowlands, G., Shaw, A., Jaswal, S., Smith, S., Harpham, T.: Health literacy and the social determinants of health: A qualitative model from adult learners. Health promotion international 32 (2015). doi:10.1093/heapro/dav093

23. Kickbusch, I., Pelikan, J.M., Apfel, F., Tsouros, A.D. (eds.): Health Literacy: the Solid Facts. The solid facts. World Health Organization Regional Office for Europe, Copenhagen (2013). OCLC: ocn859196415

24. Albouy-Llaty, D.M.: Littératie en santé : concept et pertinence en démocratie en santé (2016). https://www.cnle.gouv.fr/IMG/pdf/HL_CDSU_CNS_13042016_Litteratie.pdf

25. Van den broucke Stephan: La littératie en santé : un concept critique pour la santé publique. (2019). https://www. santepubliquefrance.fr/docs/ la-litteratie-en-sante-un-concept-critique-pour-la-sante-publique Accessed 2021-01-04

26. Ouane, A., Glanz, C.: Why and how Africa should invest in African languages and multilingual educationAn evidence- and practice-based policy advocacy brief. UNESCO Institute for Lifelong Learning (2010). https://unesdoc.unesco.org/ark:/48223/pf0000188642/PDF/188642eng.pdf.multi

27. Benedikter, R.: New technologies can be a force for good in Africa if they're developed from the ground (2019) http://theconversation.com/ new-technologies-can-be-a-force-for-good-in-africa-if-theyre-developed-from-the-ground-121916 Accessed 2020-09-23

28. Christie, G.P., Ratzan, S.C.: Beyond the bench and bedside: Health literacy is fundamental to sustainable health and development. Information Services \& Use 39(1-2), 79-92 (2019). Publisher: IOS Press. Accessed 2020-09-30

29. Royston, G., Pakenham-Walsh, N., Zielinski, C.: Universal access to essential health information: accelerating progress towards universal health coverage and other SDG health targets 5(5), 002475. doi:10.1136/bmjgh-2020-002475. Publisher: BMJ Specialist Journals Section: Analysis. Accessed 2021-02-10

30. Macrotrends: Sub-Saharan Africa Rural Population 1960-2020. https://www .macrotrends.net/countries/SSF/sub-saharan-africa-/rural-population Accessed 2020-11-30

31. Snyder, H.: Literature review as a research methodology: An overview and guidelines 104, 333-339. doi:10.1016/j.jbusres.2019.07.039. Accessed 2021-02-09

32. Liberati, A., Altman, D.G., Tetzlaff, J., Mulrow, C., Gøtzsche, P.C., loannidis, J.P.A., Clarke, M., Devereaux, P.J., Kleijnen, J., Moher, D.: The PRISMA Statement for Reporting Systematic Reviews and Meta-Analyses of Studies That Evaluate Health Care Interventions: Explanation and Elaboration. PLOS Medicine 6(7), 1000100 (2009). doi:10.1371/journal.pmed.1000100. Publisher: Public Library of Science. Accessed 2020-11-24

33. Burnham, J.F.: Scopus database: a review. Biomedical digital libraries 3(1), 1-8 (2006)

34. Vine, R.: Google scholar. Journal of the Medical Library Association 94(1), 97 (2006)

35. Davies, K.S.: Formulating the evidence based practice question: A review of the frameworks $6(2), 75-80$ doi:10.18438/B8WS5N. Number: 2. Accessed 2021-02-09

36. Haneem, F., Kama, N., Ali, R., Selamat, A.: Applying Data Analytics Approach in Systematic Literature Review: Master Data Management Case Study. doi:10.3233/978-1-61499-800-6-705

37. Matt Vassar, M.J.K. Paul Atakpo: Manual search approaches used by systematic reviewers in dermatology | Vassar | Journal of the Medical Library Association 104 (2016). doi:10.5195/jmla.2016.145. Accessed 2021-01-06

38. Zygomatic: Free online word cloud generator and tag cloud creator. https://www.wordclouds. com/ Accessed 2021-01-24

39. Nchise, A.C., Boateng, R., Shu, I., Mbarika, V.: Mobile phones in health care in uganda: The AppLab study 52(1), 1-16. doi:10.1002/j.1681-4835.2012.tb00367.x

40. voices for a Malaria-Free Future: Malaria Free Future (2010). https://www.malariafreefuture.org/mtn Accessed 2021-01-09

41. Chib, A., Wilkin, H., Ling, L.X., Hoefman, B., Biejma, H.V.: You Have an Important Message! Evaluating the Effectiveness of a Text Message HIV/AIDS Campaign in Northwest Uganda. Journal of Health Communication 17(sup1), 146-157 (2012). doi:10.1080/10810730.2011.649104. Publisher: Taylor \& Francis_eprint: https://doi.org/10.1080/10810730.2011.649104. Accessed 2021-01-04

42. GSMA: Young Africa Live (2009). https://www.gsma.com/mobilefordevelopment/wp-content/uploads/ 2016/02/Case_Study_-YoungAfricaLive.pdf

43. Johnson, D., Juras, R., Riley, P., Chatterji, M., Sloane, P., Choi, S.K., Johns, B.: A randomized controlled trial of the impact of a family planning mhealth service on knowledge and use of contraception. Contraception 95(1), 90-97 (2017)

44. LeFevre, A.E., Mohan, D., Hutchful, D., Jennings, L., Mehl, G., Labrique, A., Romano, K., Moorthy, A.: Mobile Technology for Community Health in Ghana: what happens when technical functionality threatens the effectiveness of digital health programs? BMC Medical Informatics and Decision Making 17(1), 27 (2017). doi:10.1186/s12911-017-0421-9. Accessed 2021-01-04

45. AFD: Text messages to raise awareness about health and hygiene (2020). https://www.afd.fr/en/actualites/text-messages-raise-awareness-about-health-and-hygiene/ Accessed 2020-12-18 
46. Wolfe, N., Hong, J., Rosenfeld, R., Raj, B., Raza, A.A.: Rapid Development of Public Health Education Systems in Low-Literacy Multilingual Environments: Combating Ebola Through Voice Messaging (2015). doi:10.13140/RG.2.1.1885.6405

47. Vaz, N.F.M., Vaz, N.F.M.: Mobile Health Literacy to Improve Health Outcomes in Low-Middle Income Countries. http://services.igi-global.com/resolvedoi/resolve.aspx?doi=10.4018/978-1-5225-3926-1.ch070 6(4), 13 (2017). doi:10.4018/IJRQEH.2017100102. Archive Location:

mobile-health-literacy-to-improve-health-outcomes-in-low-middle-income-countries ISBN: 9781522539261 Publisher: IGI Global. Accessed 2021-01-04

48. Lori, J.R., Munro, M.L., Boyd, C.J., Andreatta, P.: Cell Phones to Collect Pregnancy Data From Remote Areas in Liberia. Journal of Nursing Scholarship 44(3), 294-301 (2012). doi:10.1111/j.1547-5069.2012.01451.x. Accessed 2021-01-04

49. Li, W., Han, L.Q., Guo, Y.J., Sun, J.: Using WeChat official accounts to improve malaria health literacy among Chinese expatriates in Niger: an intervention study. Malaria Journal 15 (2016). doi:10.1186/s12936-016-1621-y. Accessed 2021-01-04

50. Wagstaff, A., Doorslaer, E.v., Burger, R.: SMS nudges as a tool to reduce tuberculosis treatment delay and pretreatment loss to follow-up. a randomized controlled trial 14(6), 0218527. doi:10.1371/journal.pone.0218527. Publisher: Public Library of Science. Accessed 2021-02-09

51. Haricharan, H.J., Heap, M., Hacking, D., Lau, Y.K.: Health promotion via SMS improves hypertension knowledge for deaf South Africans. BMC Public Health 17(1), 663 (2017). doi:10.1186/s12889-017-4619-7. Accessed 2021-01-04

52. Rosenthal, J.W.: Summary of Project Masiluleke case study describing design process for fighting HIV/AIDS in South Africa. (2011). http://designobserver.com/feature/ project-masiluleke-texting-and-testing-to-fight-hiv-aids-in-south-africa/28918 Accessed 2021-01-09

53. Avert: Global information and education on HIV and AIDS in South Africa (2015). https://www . avert.org/professionals/hiv-around-world/sub-saharan-africa/south-africa Accessed 2021-01-04

54. Mukami, D.: M-learning gives Kenyan nurses scalable continuing education. Technical report (2016). https: //www.elsevier.com/connect/m-learning-gives-kenyan-nurses-scalable-continuing-education Accessed 2021-01-04

55. Iheed: mHealth Education: Harnessing the Mobile Revolution to Bridge the Health Education \& Training Gap in Developing Countries. Iheed Report. https://www. iheed.org/wp-content/uploads/iheedreport_2011.pdf

56. Tilahun, D., Hanlon, C., Araya, M., Davey, B., Hoekstra, R.A., Fekadu, A.: Training needs and perspectives of community health workers in relation to integrating child mental health care into primary health care in a rural setting in sub-saharan africa: a mixed methods study. International journal of mental health systems $11(1)$ 1-11 (2017)

57. Mushamiri, I., Luo, C., liams-Hauser, C., Amor, Y.B.: Evaluation of the impact of a mobile health system on adherence to antenatal and postnatal care and prevention of mother-to-child transmission of hiv programs in kenya. BMC public health 15(1), 1-16 (2015)

58. FHI360: ICT Use to Improve Information access at the Point of Care (2013). https://solutionscenter.nethope.org/assets/collaterals/FHI360_TechLab_MHIS_CaseStudy.pdf Accessed 2021-02-09

59. United States Agency, for International Development: m-health Compendium Volume 5 (2015). http://www . africanstrategies4health.org/uploads/1/3/5/3/13538666/mhealth_vol5_final_fr.pdf Accessed 2021-01-07

60. Yow, V., et al.: Using SMS for social mobilization and reporting on the Ebola outbreak (2019). https://lib.digitalsquare.io/bitstream/handle/123456789/77565/ebola_txt.pdf?sequence=1

61. Krenn, S., Cobb, L., Babalola, S., Odeku, M., Kusemiju, B.: Using behavior change communication to lead a comprehensive family planning program: the nigerian urban reproductive health initiative. Global Health: Science and Practice 2(4), 427-443 (2014)

62. Mwaikambo, L., Dolphyne, A.: Leveraging open-source technology and adapting open elearning content to improve the knowledge and motivation of ghana's rural nurses. Knowledge Management \& E-Learning: An International Journal 8(1), 55-67 (2016)

63. UNICEF: U-Report Reaches 2 Million Nigerian Responders (2017). https://www.unicef .org/innovation/ U-Report/social-media-platform-reaches-2-million-Nigerian-responders Accessed 2021-01-09

64. Watkins, J.O.T.A., Goudge, J., Gómez-Olivé, F.X., Griffiths, F.: Mobile phone use among patients and health workers to enhance primary healthcare: A qualitative study in rural south africa. Social Science \& Medicine 198 139-147 (2018)

65. VIAMO: 3-2-1 Service:improving lives via mobile. https://viamo.io/fr/services/le-service-3-2-1/ Accessed 2021-01-24

66. Die, Z.M.: A Global Initiative to Save the Lives of Pregnant Women \& their Newborns Using Mobile Technologies (2017). http://www .zeromothersdie.org/ Accessed 2021-01-09

67. Kabongo, E.M., Mukumbang, F.C., Delobelle, P., Nicol, E.: Understanding the influence of the MomConnect programme on antenatal and postnatal care service utilisation in two South African provinces: a realist evaluation protocol. BMJ Open 9(7), 029745 (2019). doi:10.1136/bmjopen-2019-029745. Publisher: British Medical Journal Publishing Group Section: Health services research. Accessed 2021-01-09

68. e-health OBSERVATORY: MY VIRTUAL PLANNING prevents unwanted pregnancies by educating young people about sexuality, and by facilitating access and effective use of modern contraceptives thanks to digital technology (2019). https://www.odess.io/initiative-detail/my-virtual-planning.html Accessed 2021-01-09

69. e-health OBSERVATORY: YAAY.SN a platform for mothers online, educational and offering everyday decision-making tools (2017). 
https://www.odess.io/initiative-detail/yaay-sn-yaaymaman-en-wolof.html Accessed 2021-01-09

70. e-health OBSERVATORY: m-NUTRITION contribute to preventing and reducing chronic malnutrition, through access to nutrition information via mobile technology (2018).

https://www.odess.io/initiative-detail/m-nutrition.html Accessed 2021-01-09

71. e-health OBSERVATORY: TBIBCOM support platform for patients with chronic diseases for the follow-up of complications and therapeutic education of patients (2017).

https://www.odess.io/initiative-detail/tbibcom.html Accessed 2021-01-09

72. Hudig, F.: Apprendre à Vivre (Learning about Living) (2012).

https://oxfamilibrary .openrepository.com/bitstream/handle/10546/229473/

cs-learning-living-senegal-2012_1; jsessionid=98C27000F1E7D2D0B5ECD3A2F78E7CCC? sequence=1

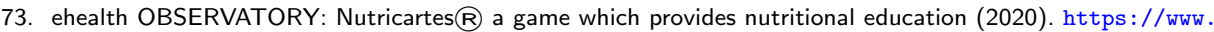
odess.io/initiative-detail/application-sur-telephone-androide-du-jeu-nutricartes-928.html Accessed 2021-01-09

74. e-health OBSERVATORY: ASCA sending monthly written messages to patients suffering from mental illnesses under treatment to remind them of their day of visit to the health centres (2019). https://www.odess.io/initiative-detail/asca-benin.html Accessed 2021-01-09

75. L'Engle, K., Plourde, K.F., Zan, T.: Evidence-based adaptation and scale-up of a mobile phone health information service. mHealth 3 (2017). doi:10.21037/mhealth.2017.02.06. Accessed 2021-01-04

76. LeFevre, A.E., Mohan, D., Hutchful, D., Jennings, L., Mehl, G., Labrique, A., Romano, K., Moorthy, A.: Mobile technology for community health in ghana: what happens when technical functionality threatens the effectiveness of digital health programs? BMC medical informatics and decision making 17(1), 1-17 (2017)

77. (WHO): A universal truth: no health without a workforce. WHO (2014). https://www. who.int/workforcealliance/knowledge/resources/GHWA-a_universal_truth_report.pdf

78. Kamsu-Foguem, B., Foguem, C.: Could telemedicine enhance traditional medicine practices? European Research in Telemedicine / La Recherche Européenne en Télémédecine 3(3), 117-123 (2014). doi:10.1016/j.eurtel.2014.08.001. Accessed 2021-01-01

79. Feroz, A., Jabeen, R., Saleem, S.: Using mobile phones to improve community health workers performance in low-and-middle-income countries. BMC Public Health 20(1), 49 (2020). doi:10.1186/s12889-020-8173-3. Accessed 2021-01-04

80. WHO: World Health Organization (WHO)| The Abuja Declaration: Ten Years On. Publisher: World Health Organization. http://www. who.int/healthsystems/publications/abuja_declaration/en/Accessed 2021-01-04

81. Straumann, M.G.R.: Where do Most of the Internet Users Live? | University of Oxford. https://www.ox.ac.uk/news/2015-07-13-where-do-most-internet-users-live Accessed 2021-02-09

82. Assogba, C.: Le Taux D'accès à Internet Reste Faible en Afrique. https://www.scidev.net/afrique-sub-saharienne/news/taux-acces-internet-faible-afrique/ Accessed 2021-01-04

83. Källander, K., Tibenderana, J., Akpogheneta, O., Strachan, D., Hill, Z., ten Asbroek, G., Conteh, L., Kirkwood, B., Meek, S.: Mobile Health (mHealth) Approaches and Lessons for Increased Performance and Retention of Community Health Workers in Low- and Middle-Income Countries: A Review. Journal of medical Internet research 15, 17 (2013). doi:10.2196/jmir.2130

84. Olu, O., Muneene, D., Bataringaya, J.E., Nahimana, M.-R., Ba, H., Turgeon, Y., Karamagi, H.C., Dovlo, D. How Can Digital Health Technologies Contribute to Sustainable Attainment of Universal Health Coverage in Africa? A Perspective. Frontiers in Public Health 7 (2019). doi:10.3389/fpubh.2019.00341. Accessed 2021-01-04

85. Aranda-Jan, C.B., Mohutsiwa-Dibe, N., Loukanova, S.: Systematic review on what works, what does not work and why of implementation of mobile health (mHealth) projects in Africa. BMC Public Health 14(1), 188 (2014). doi:10.1186/1471-2458-14-188. Accessed 2021-01-04

86. Early, J., Gonzalez, C., Gordon-Dseagu, V., Robles-Calderon, L.: Use of Mobile Health (mHealth) Technologies and Interventions Among Community Health Workers Globally: A Scoping Review. Health Promotion Practice 20(6), 805-817 (2019). doi:10.1177/1524839919855391. Publisher: SAGE Publications. Accessed 2021-01-04

87. Dharmayat, K.I., Tran, T., Hardy, V., Chirambo, B.G., Thompson, M.J., Ide, N., Carlsson, S., Andersson, B., O'Donoghue, J.M., Mastellos, N.: Sustainability of 'mHealth' interventions in sub- Saharan Africa: a stakeholder analysis of an electronic community case management project in Malawi. Malawi Medical Journal 31(3), 177-183 (2019). doi:10.4314/mmj.v31i3.3. Accessed 2021-01-04

88. Nadal, C., Sas, C., Doherty, G.: Technology Acceptance in Mobile Health: Scoping Review of Definitions, Models, and Measurement. Journal of Medical Internet Research 22(7), 17256 (2020). doi:10.2196/17256. Company: Journal of Medical Internet Research Distributor: Journal of Medical Internet Research Institution: Journal of Medical Internet Research Label: Journal of Medical Internet Research Publisher: JMIR Publications Inc., Toronto, Canada. Accessed 2021-01-24 

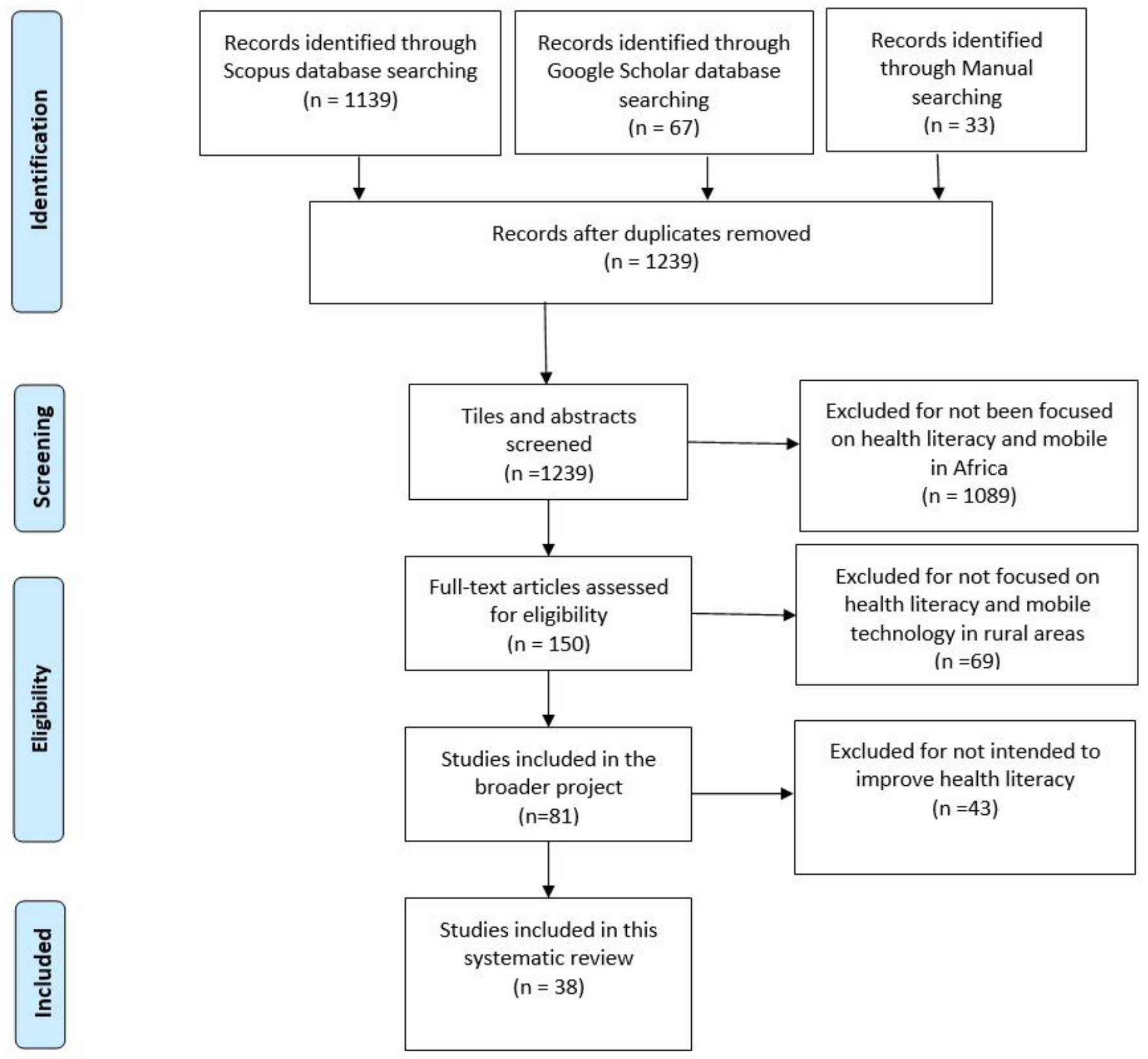

\section{Figure 1}

Method used for the systematic literature review 


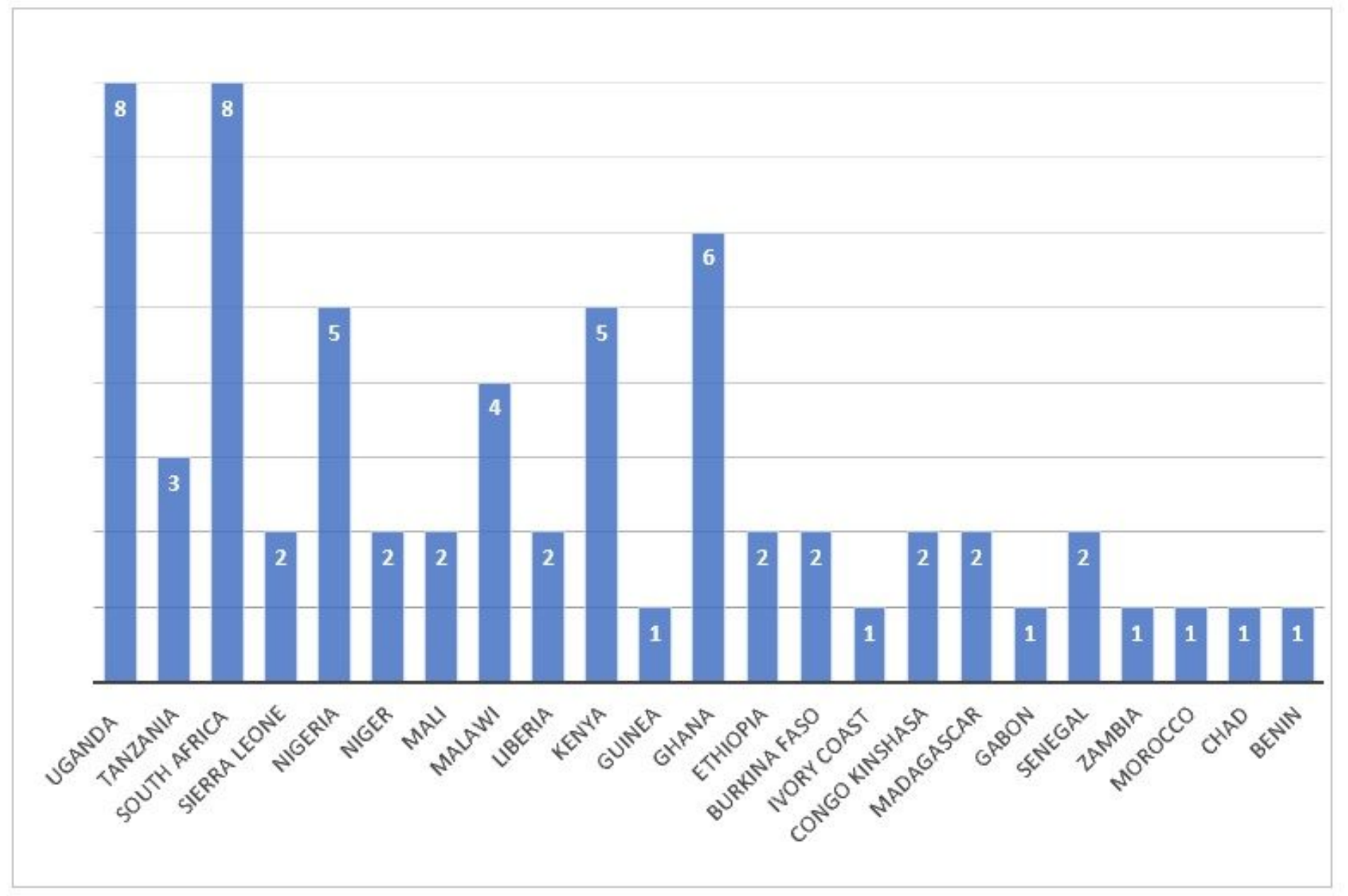

Figure 2

Targeted countries by the different studies 


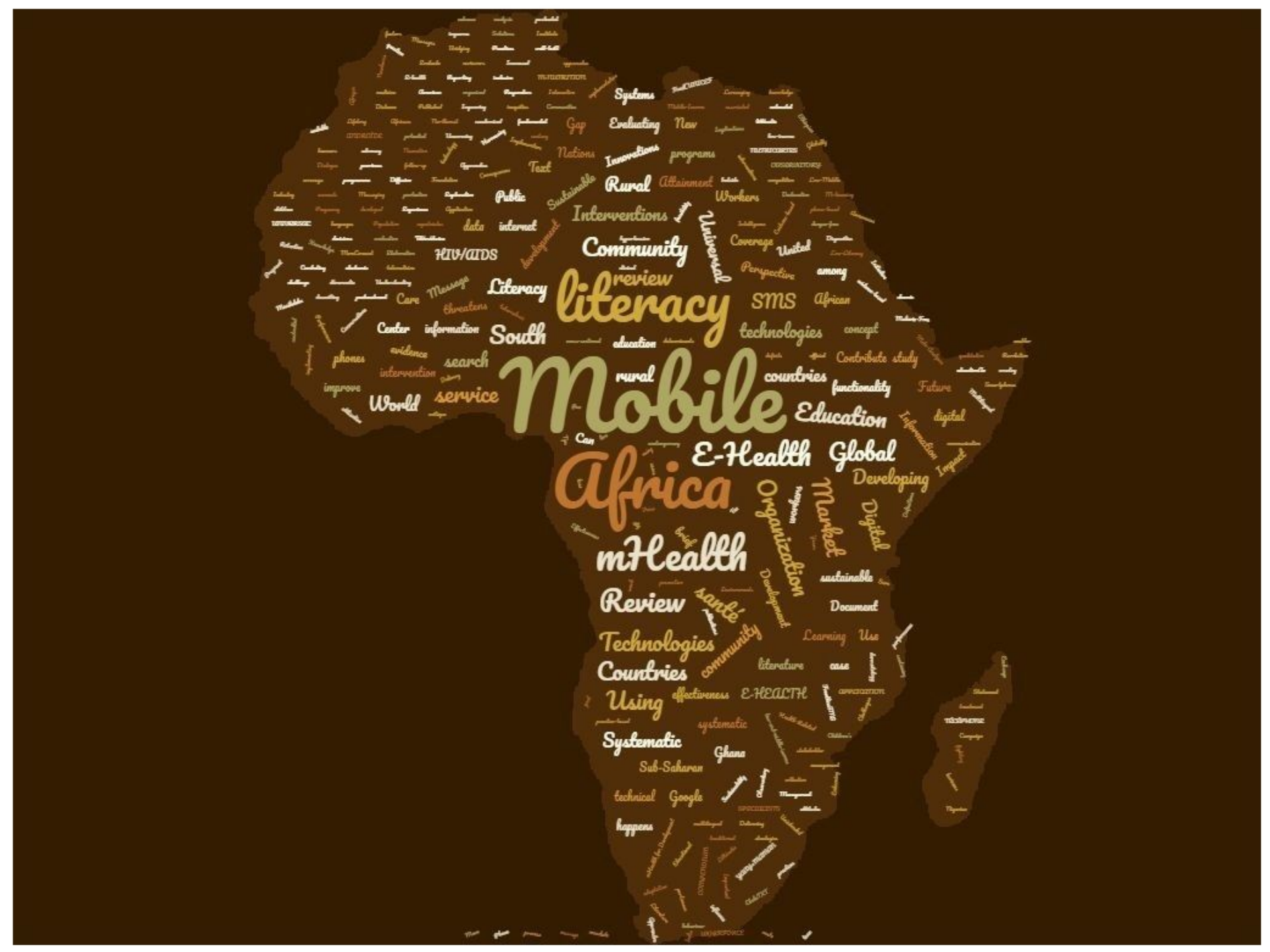

Figure 3

Highlights of the main terms encoutered in the reviewed studies 